\author{
(c) (i) (8) \\ Jurnal Terapan Manajemen dan Bisnis is licensed under \\ A Creative Commons Attribution-Non_Commercial 4.0 International License.
}

\title{
VAS KOPI (VAS KOREK API) AS A CREATIVE AND INNOVATIVE EFFORT FOR STKIP SINGKAWANG STUDENTS
}

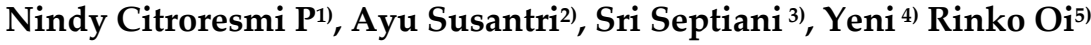 \\ 1) STKIP Singkawang, Singkawang, Indonesia \\ E-mail: nindycitroresmip@gmail.com \\ 2) STKIP Singkawang, Singkawang, Indonesia \\ E-mail: Ayususantri12@gmail.com \\ 3) STKIP Singkawang, Singkawang, Indonesia \\ E-mail: Sri Septiani @gmail.com \\ 4) STKIP Singkawang, Singkawang, Indonesia \\ E-mail: yeniyeni0112@gmail.com \\ 5) Meio University, Nago, Japan \\ E-mail: rinko.oi.9827@gmail.com
}

\begin{abstract}
The entrepreneurship program entitled VAS KOPI (Vase of Matches) As a Creative and Innovative Effort for STKIP Singkawang Students aims to develop student interest and creativity in opening business opportunities that can add experience, motivate in developing innovations and creations. One of them is by using matches.
\end{abstract}

Keywords: crafts, creativity, matches

\section{Introduction}

Most people think that matches can only be used for cooking, help lighting when the electricity is not on, and can also be a game, it turns out that they can be created into various kinds of unique art forms made of matchsticks and have a high enough selling value, of course. .

In the surrounding environment, we must have seen crafts made by creative hands to produce interesting works. Today, so many crafts are made by engine power, that it is rare to find handicrafts. Craft is a work of art whose manufacturing process uses human hand skills with various shapes and colors they like. According to Suprapto, handicrafts are handicrafts that produce art quality goods, so in the process they are made with a sense of beauty and with pure ideas so as to produce quality products that have beautiful and attractive shapes. Meanwhile, according to Wiyadi, crafts are all activities in the field of industry or the manufacture of goods which are fully carried out by diligent, skilled, tenacious and creative in their efforts to achieve them

Matches do have a small and unique shape, but they can provide great benefits in helping facilitate human life. A match (sometimes also called a lighter or lighter) is a tool to light a fire in a controlled manner. Lighters are sold freely in stores in the form of a package 
box of matches. A match consists of a stick of wood with one end covered with a material generally phosphorus which will produce a frictional flame when rubbed against a particular surface even though there are types of matches that can be lit on any rough surface. Matches crafts can be made into a variety of useful items. If used wisely, matches will become a more valuable item, so that they can provide business opportunities so that they can increase income with small capital and large profits.

In this modern era, many people spend money only to buy products or goods to complement human secondary needs. Actually, there are so many objects around us that can be used to make creative, innovative, and economical products or crafts.

A product is a product or service that can be traded, a product also has the meaning of anything that can be offered to the market that can provide satisfaction with a desire and need (Dharma, Lucitasari, and Khannan, 2018). According to Kotler (Suatma, 2013), a product is everything that is offered to a market to meet consumer needs and desires. Based on the definition of the product above, it can be concluded that a product is anything that can be bought and sold to meet consumer needs.

The product is the most important element because the product includes all the planning that precedes the production process. Craft is one type of product. There are various kinds of crafts that can be made in an effort to produce a product. To get a good product, goods that are made and produced must be designed in such a way as to be of good quality.

\section{Product design and development}

Palgunadi (Dharma, Lucitasari, and Khannan, 2018) stated that in product design and development several steps are needed to facilitate the implementation of product manufacturing, these steps are as follows.

a. Design

Design is the first step in planning the manufacture of a product that has an output in the form of a sketch of a product to be made.

b. Manufacturing

Manufacturing is a part of production, especially to determine the steps needed to manufacture a product.

c. Material planning

Material planning is planning related to production materials that will be used for product manufacturing

d. Cost planning

Cost planning is a step to estimate how much it will cost in making a product.

\section{SWOT analysis}

SWOT analysis is a strategic planning technique that is useful for evaluating your strengths, weaknesses, opportunities, and threats. The product SWOT analysis is as follows:

Table 1. SWOT analysis

\begin{tabular}{|l|l|}
\hline Strength & - Can be produced by yourself \\
& - Raw materials are easy to get \\
& - Use ordinary items to become more attractive items \\
\hline Weakness & - There is no experience in making goods that are more varied \\
& - Complicated manufacturing process \\
\hline Opportunity & - rarely do manufacturers make handicrafts from matches \\
& - Have bright and promising prospects \\
& - Opportunity to dominate the market \\
\hline
\end{tabular}




\section{Method of Implementation}

Before carrying out this effort, we will prepare a design which is divided into stages as follows:

1. Preparation Stage

To start this business, there are several things that we have to prepare, namely:

a. Business location

The location for making handicraft creations from matches will be done in Roban, because this location is very strategic which will be used as a place of production as well as product marketing.

b. Prepare matches and tools needed

The material that needs to be prepared in making handicraft creations from these matches is wooden matches, because matches are the main raw material in making this craft product. The tools needed must also be prepared to support the making of match paper craft creations.

2. Production Stage

If all the raw materials and tools have been prepared, then we are ready to carry out the next stage, namely the production stage, where the matches we process into crafts and crafts are the basic ingredients of making products, then they are created into various products.

3. Promotion Stage

Promotion can be done in several ways including direct promotion to prospective buyers, making sales stands at an exhibition, through social media and brochures.

4. The Marketing Stage

We started marketing by directly offering products to prospective buyers, then we also marketed products through social media to expand marketing.

\section{Output Results}

The outputs of this activity include:

1. The manufacturing process is handmade

Products that are made by handmade are generally designed in great detail, so that the products produced are usually different and unique from one product to another.

2. These matches can produce a variety of handicraft products

These matches can be processed into several handicraft products, such as flower vases, wall hangings, miniatures of houses and many others.

3. The handicraft products are priced in accordance with the quality of the products produced

These plastic flowers are processed properly, then they are produced using quality materials. So that the products produced are of high quality, this is what will affect the price of our products. The more complicated the work, the higher the price offered. 
Jurnal Terapan Manajemen dan Bisnis

Volume 6 Number 1 march 2020. Page 8-12

e-ISSN: 2477-5282 p-ISSN: 2599-3127

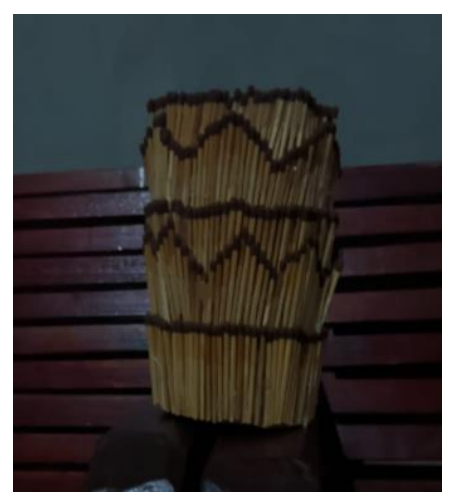

Picture 1

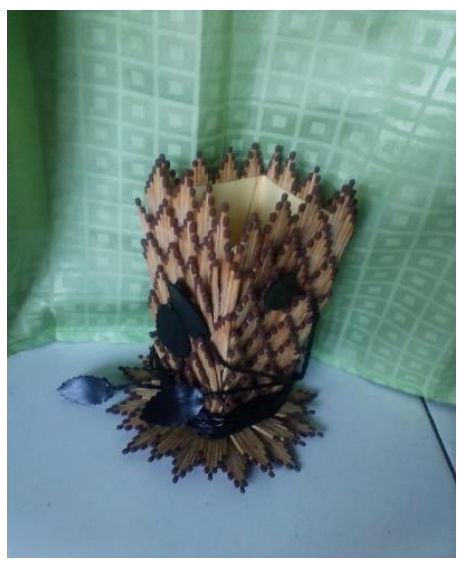

Picture 2

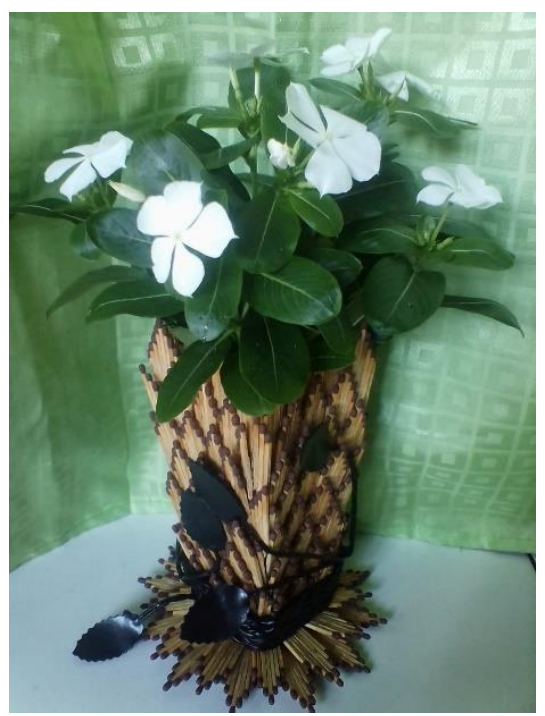

Picture 3 


\section{Conclusion}

A match is a tool to light a fire in a controlled manner. Matches are made of various materials, one of which is wood. A wood lighter consists of a wooden stick with one end covered with a material generally phosphorus which will produce a flame due to friction with a special surface. In addition to lighting a fire, wooden matches are also useful for making interesting and valuable handicraft products, one of which is a flower vase. The cost of making a vase from wooden matches is not too expensive.

\section{References}

Dharma, Lucitasari, dan Khannan. 2018. Perancangan Ulang Headset dan Penutup mata untuk tidur menggunakan metode Nigel Cross. Jurnal Optimasi Sistem Industri, 11 (1), 65-77.

Kartika. 2020. Mengapa Perlu Analisis SWOT untuk Perusahaan?. https://www.jurnal.id/id/blog/analisis-swot-untuk-perusahaan/.

Nindyanrul..http://nindyanrul.blogspot.com/2017/12/pengertian-kerajinan-menurut-paraahli.html. 19 Desember 2017

Suatma. 2013. Analisis Strategi Inovasi Atribut Produk dan Pengaruhnya Terhadap Keputusan Pembelian Konsumen pada Skuter Matik Merek Honda Vario di Kota Semarang. Jurnal STIE Semarang, 5 (2), 19-35. 